\title{
Analisis Kemampuan Membayar Dan Kemauan Membayar Peserta PBPU JKN Di Kecamatan Tamalate Kota Makassar
}

\section{Analysis on the Ability to Pay and Willingness to Pay of PBPU JKN Participants in Tamalate Sub-District, Makassar City}

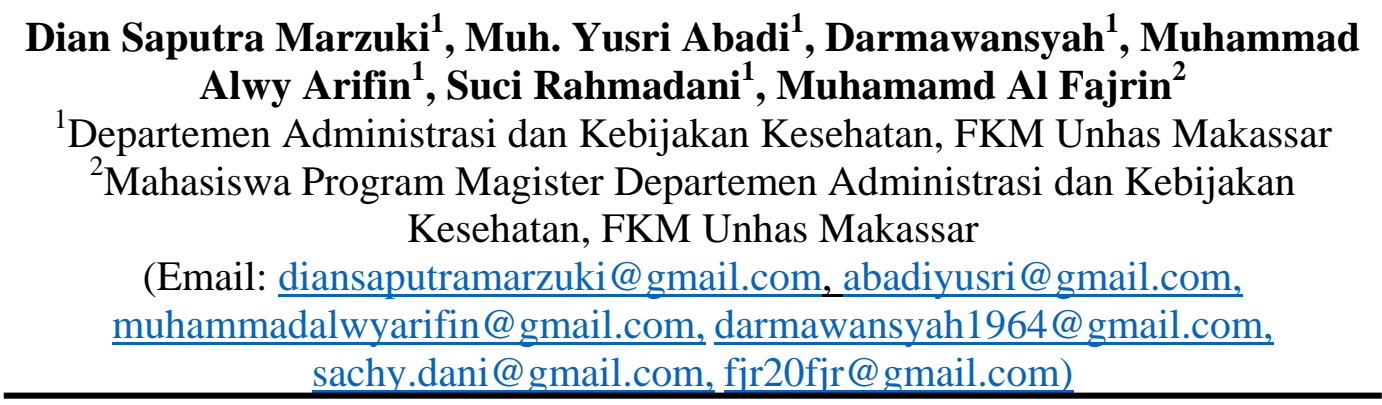

\section{ABSTRAK}

Tercatat jumlah peserta BPJS Kesehatan yang memiliki tunggakan khususnya di Kota Makassar per Desember 2017 sebanyak 143.794 jiwa penduduk. Tujuan penelitian ini untuk Menganalisis Kemampuan Membayar (ATP) dan Kemauan Membayar (WTP) Peserta PBPU yang menunggak iuran Jaminan Kesehatan Nasional di Kecamatan Tamalate Kota Makassar. Desain penelitian ini adalah penelitian kuantitatif dengan pendekatan survei deskriptif. Populasi dalam penelitian ini adalah seluruh peserta peserta PBPU yang menunggak iuran jaminan kesehatan nasional di kecamatan tamalate kota Makassar. Sampel dalam penelitian ini sebanyak 100 sampel. Hasil yang diperoleh dari penelitian yaitu responden ATP 1 kategori mampu yaitu 61\% dan tidak mampu 39\%, ATP 2 non makanan berada mampu yaitu $46 \%$ untuk non-essensial kategori mampu yaitu 21\%. Pada aspek kemauan membayar tunggakan responden kategori tidak mau yaitu sebanyak 70 responden (70\%), kategori mau yaitu sebanyak 30 responden (30\%). Pengetahuan mengenai tarif JKN yaitu $42 \%$. Responden/anggota keluarga yang memiliki riwayat penyakit katastropik adalah $27 \%$ jenis penyakit terbanyak adalah stroke.

\section{Kata Kunci: Jaminan Kesehatan Nasional, ATP, WTP}

\section{ABSTRACT}

The number of participants of BPJS (The Social Security Administrator) Health Insurance's with payment arrears particularly in Makassar City as recorded per December 2017 is around 143.794 people. The purpose of this research is to analyze the Ability to Pay (ATP) and the Willingness to Pay (WTP) of Non-Wage Recipient Participants (PBPU) with those arrears of dues on National Health Insurance (JKN) in Tamalate Sub-district, Makassar City. This research is designed in quantitative research with descriptive-survey approach. The population of this research is all participants of $P B P U$ who default the dues of National Health Insurance in Tamalate Sub-district of Makassar City. Samples selected for this study are around 100 samples. The results obtained from the research indicate that ATP 1 for capable respondent category appears at $61 \%$, and for the incapable at 39\%. ATP 2 for capable category of non-food shows at $46 \%$, and for capable category of non-essential at $21 \%$. Whereas on the Willingness to Pay the arrears, category of unwillingness reaches upon 70 respondents (70\%), while for the opposite category (willingness) only rises as many as 30 respondents (30\%). In addition, the knowledge on the rates of JKN is at $42 \%$. The number of respondents or family members with history of catastrophic disease is about 27\%, and mostly, type of the disease are strokes.

Keywords: National Health Insurance, Ability To Pay (ATP), Willingness To Pay (WTP) 


\section{PENDAHULUAN}

Pelaksanaan program Jaminan Kesehatan Nasional-Kartu Indonesia Sehat (JKN-KIS) di Indonesia masih jauh dari target. Berdasarkan data Badan Penyelenggara Jaminan Sosial (BPJS) Kesehatan, sampai dengan 17 Maret 2017 peserta JKN-KIS telah mencapai 175 juta jiwa dari beberapa segmen kepesertaan, dan baru 70\% penduduk Indonesia yang telah menjadi peserta JKN-KIS. Dari jumlah tersebut, sebanyak 25 juta peserta (beserta keluarga) merupakan pekerja yang didaftarkan oleh sang pemberi kerja. Dari 261 juta penduduk Indonesia dan berdasarkan data kasar BPJS Kesehatan menunjukkan bahwa 70 hingga 80 juta penduduk Indonesia belum memiliki jaminan kesehataan, sehingga direktur BPJS Kesehatan menargetkan hingga akhir tahun ini, 261 juta data dari Kemdendagri yang belum terdaftar akan segera di antisipasi oleh pihak BPJS Kesehatan (BPJS, 2017). Berdasarkan data BPJS Kesehatan peserta yang sudah terdaftar JKN di Indonesia adalah sebanyak 222.463.022 per 1 Juli 2019 dengan total PBI APBN sebanyak 96.637.268, PBI APBD sebanyak 36.905.446, PPU-PN sebanyak 17.470.358, PPU-BU sebanyak 34.008.295, PBPU-Pekerja Mandiri sebanyak 32.289.326 dan Bukan Pekerja sebanyak 5.152.329 jiwa (BPJS, 2019).

Data Badan Pusat Statistik Penduduk Provinsi Sulawesi Selatan sebanyak 9.426.853 jiwa (BPS, 2018) dan yang sudah menjadi Peserta JKN-KIS yaitu 8.411.467 jiwa pada tahun 2019 (BPJS, 2019). Jadi 89\% jumlah penduduk yang menjadi peserta BPJS di Sulawesi Selatan. Sedangkan data dari Badan Pusat Statistik (BPS) Tahun 2019 bahwa di Sulawesi Selatan tepatnya di Kota Makassar dengan jumlah penduduk 1.663.479 jiwa penduduk yang sudah terdaftar sebagai Peserta BPJS sebanyak 1.286.925 jiwa atau 77,36 \% dan jumlah masyarakat yang belum terdaftar sebagai peserta JKN-KIS yaitu 376.554 jiwa atau 22,64 \% (BPS, 2018).

Saat ini tercatat jumlah peserta BPJS Kesehatan yang memiliki tunggakan khususnya di Kota Makassar per Desember 2017 sebanyak 143.794 jiwa penduduk yang menunggak iuran BPJS. Berdasarkan kelas kepesertaan yang paling tinggi jumlah tunggakannya yaitu kelas 3 sebanyak 125.386 penduduk yang menunggak di kota Makassar atau 53,90 \% Peserta Non PBI Bukan 
Penerima Bantuan Iuran yang memiliki tunggakan terbesar. Kepesertaan tertinggi kedua tunggakannya yaitu kelas 1 memiliki jumlah tunggakan 58.780 jiwa atau 25,27\% Peserta Non PBI Bukan Penerima Upah, dan untuk kepesertaan kelas 2 memiliki jumlah tunggakan 48,439 atau 20,82\% Peserta Non PBI Bukan Penerima Upah (BPJS, 2017). Data sekunder yang di peroleh peneliti di BPJS Kesehatan jumlah peserta Non PBI Bukan Penerima Upah di Kota Makassar dari beberapa Kecamatan yang memiliki tunggakan yaitu Kecamatan Tamalate sebanyak 17.102 jiwa, Kecamatan Biringkanaya 16.379 jiwa, Kecamatan Rappocini 15.588 jiwa, Kecamatan Tallo 15.082 jiwa, Kecamatan Manggala 15.065 jiwa, Kecamatan Panakukang 14.795, Kecamatan Sombo Opu 13.868 jiwa, Kecamatan Makassar 10.138 jiwa, Kecamatan Mariso 8.912 jiwa, Kecamatan Palangga 8.489 jiwa dan Kecamatan Bontonompo 8.376 jiwa (BPJS, 2017). Berdasarkan latar belakang maka penulis tertarik untuk meneliti Analisis Kemampuan Membayar (ATP) dan Kemauan Membayar (WTP) Tunggakan Iuran Peserta PBPU Jaminan Kesehatan Nasional di Kecamatan Tamalate Kota Makassar.

\section{METODE}

Pada penelitian ini, peneliti menggunakan metode penelitian kuantitatif dengan pendekatan survei deskriptif yang digunakan untuk menghasilkan suatu gambaran mengenai kemampuan dan kemauan membayar iuran jaminan kesehatan nasional pada masyarakat di Kecamatan Tamalate kota Makassar. Penelitian ini dilaksanakan di Kecamatan Tamalate Kota Makassar, dengan objek penelitian difokuskan pada kemampuan dan kemauan membayar iuran jaminan kesehatan nasional pada masyarakat Kecamatan Tamalate Kota Makassar yang memiliki tunggakan iuran BPJS. Populasi dalam penelitian ini adalah seluruh peserta peserta PBPU yang menunggak iuran jaminan kesehatan nasional di Kecamatan Tamalate Kota Makassar. Sampel dalam penelitian ini adalah kepala keluarga masyarakat atau anggota keluarga masyarakat Kecamatan Tamalate Kota Makassar yang memiliki tunggakan iuran BPJS. Adapun variabel yang diamati adalah Pendapatan, pengeluaran, kemauan membayar normatif, kemauan membayar aktual, pengetahuan mengenai tarif, riwayat penyakit katastropik. Data 
mengenai kemampuan membayar dan kemauan membayar masyarakat diambil menggunakan kuesioner dengan menggunakan metode wawancara. Data diolah secara komputerisasi dengan menggunakan SPSS yang dianalisis kemudian menghasilkan distribusi frekuensi dan persentase dari tiap variabel kemudian disajikan dalam bentuk tabel dan narasi.

\section{HASIL}

Karasteristik umum responden merupakan ciri khas yang melekat pada diri responden. Karakteristik responden yang ditampilkan meliputi jenis kelamin, umur, status pernikahan, pendidikan terakhir, jumlah anggota keluarga, pekerjaan.

Tabel 1. Distribusi Responden Berdasarkan Karakteristik Responden Pada Peserta yang Menunggak Iuran JKN Kecamatan Tamalate Kota Makassar Tahun 2019

\begin{tabular}{ccc}
\hline Kategori Karakteristik Responden & Jumlah (n) & $\begin{array}{c}\text { Persentase } \\
(\%)\end{array}$ \\
\hline Jenis Kelamin & 26 & 26 \\
Laki-laki & 74 & 74 \\
Perempuan & 6 & 6 \\
\hline Umur (Tahun) & 7 & 7 \\
$20-24$ & 18 & 18 \\
$25-29$ & 19 & 19 \\
$30-34$ & 12 & 12 \\
$35-39$ & 15 & 15 \\
$40-44$ & 23 & 23 \\
45-49 & & \\
$\geq 50$ & 83 & 83 \\
Nikah & 5 & 5 \\
Belum Nikah & 9 & 9 \\
Duda/Janda & 3 & 3 \\
Berpisah & & \\
\hline Status Pernikahan & 4 & 4 \\
Tidak Sekolah & 6 & 6 \\
SD (Tidak Tamat) & 11 & 11 \\
SD (Tamat) & 23 & 23 \\
SLTP/Sederajat & 39 & 39 \\
SMU/Sederajat & 8 & 8 \\
Diploma/Sederajat & 9 & 9 \\
Universitas/Sekolah Tinggi & & \\
\hline Pendidikan Terakhir & 37 & 37 \\
1-3 & 58 & 58 \\
7-6 9 & 5 & 5 \\
\hline Jumlah Anggota Keluarga & &
\end{tabular}


Dian Saputra Marzuki, Muh. Yusri Abadi : Analysis on the Ability to ....

\begin{tabular}{lcc}
\hline Kategori Karakteristik Responden & Jumlah (n) & $\begin{array}{c}\text { Persentase } \\
(\%)\end{array}$ \\
\hline Pekerjaan & 6 & 6 \\
Pegawai Swasta & 13 & 13 \\
Wiraswasta & 2 & 2 \\
Pedagang Pasar & 1 & 1 \\
kulih bangunan & 6 & 6 \\
Buruh Harian & 2 & 2 \\
Pembantu IRT & 58 & 58 \\
IRT & 12 & 12 \\
Lainnya & & \\
\hline
\end{tabular}

Berdasarkan tabel 1 sebagian besar responden berjenis kelamin perempuan sebanyak 74 responden (74\%) pada kelompok umur >50 tahun (23\%) dengan tingkat pendidikan terakhir SMA sebanyak 39 responden (36\%). Untuk pekerjaan kebanyakan responden adalah ibu rumah tangga yaitu 58 responden (58\%) dan responden dengan status pernikahan lebih banyak yang menikah yaitu 83 responden (83\%) serta jumlah anggota keluarga responden paling banyak 4-6 orang yaitu 58 responden (58\%).

Tabel 2. Distribusi responden berdasarkan variabel independen (Pendapatan dan Pengeluaran) pada peserta tunggakan iuran JKN Kecamatan Tamalate Kota Makassar Tahun 2019

\begin{tabular}{ccc}
\hline Variabel independen (Pendapatan dan Pengeluaran) & Jumlah & $\begin{array}{c}\text { Persentase } \\
\text { (\%) }\end{array}$ \\
\hline Pendapatan (Rp) & 14 & 14 \\
$<1.500 .000$ & 4 & 4 \\
$1.500 .001-1.999 .999$ & 34 & 34 \\
$2.000 .000-2.499 .999$ & 10 & 10 \\
$2.500 .000-2.999 .999$ & 38 & 38 \\
$\geq 3.000 .000$ & & \\
Makanan (Rp) & 12 & 12 \\
$<500.000$ & 40 & 40 \\
$500.000-999999$ & 27 & 27 \\
$1.000 .000-1499.999$ & 21 & 21 \\
$\geq 1.500 .000$ & & \\
Pengeluaran & 54 & 54 \\
<on Makanan (Rp) & 25 & 25 \\
500.000 & 21 & 21 \\
$\geq 1.000 .000$ & & \\
Pengeluaran & 76 & 76 \\
<0n Esensial (Rp) & 24 & 24 \\
\hline Pen.000 & & \\
\hline
\end{tabular}

Berdasarkan hasil pada pendapatan per bulan responden yang terbanyak yaitu $\geq$ Rp.3.000.000,- sebanyak 38 responden (38\%), Pengeluaran makanan 
responden terbanyak Rp.500.000-Rp.999.999 yaitu 40 responden (40\%), pengeluaran non makanan sebanyak <Rp.500.000,- yaitu 54 responden (54\%), dan pengeluaran non esensial <Rp.500.000,- semua responden 76 (76\%) (Tabel 2).

Tabel 3. Distribusi Responden Berdasarkan Variabel Independen (ATP 1 dan ATP 2) dan WTP Pada Peserta Tunggakan Iuran JKN Kecamatan Tamalate Kota Makassar Tahun 2019

\begin{tabular}{|c|c|c|}
\hline Variabel independen (ATP 1 dan ATP 2) & Jumlah & Persentase (\%) \\
\hline \multicolumn{3}{|l|}{ ATP 1} \\
\hline Mampu & 61 & 61 \\
\hline Tidak Mampu & 39 & 39 \\
\hline \multicolumn{3}{|l|}{ ATP 2 Non Makanan } \\
\hline Mampu & 46 & 46 \\
\hline Tidak Mampu & 54 & 54 \\
\hline \multicolumn{3}{|l|}{ ATP 2 Non Esensial } \\
\hline Mampu & 21 & 21 \\
\hline Tidak Mampu & 79 & 79 \\
\hline \multicolumn{3}{|l|}{ Kelas pelayanan yang diinginkan (kelas tetap) } \\
\hline Kelas 1 & 31 & 31 \\
\hline Kelas 2 & 25 & 25 \\
\hline Kelas 3 & 11 & 11 \\
\hline \multicolumn{3}{|l|}{ WTP (Kesediaan membayar total tunggakan) } \\
\hline Mau & 30 & 30 \\
\hline Tidak Mau & 70 & 70 \\
\hline
\end{tabular}

Berdasarkan hasil pada variabel independen ATP 1 yang mampu membayar iuran sebanyak 61 responden (61\%), ATP 2 non makanan yang mampu membayar iuran sebanyak 46 responden (46\%), sedangkan ATP 2 non esensial yang mampu memabayar iuran sebanyak 21 responden (21\%). Adapun kemauan membayar (WTP) untuk kelas pelayanan yang diinginkan (kelas tetap) sebanyak 67 responden (67\%). Kemuana membayar total tunggakan iuran (WTP) responden banyak yang masih tidak mau sebanyak 70 responden (70\%) (Tabel 3).

Tabel 4. Distribusi Responden Berdasarkan Pengetahuan, Riwayat Penyakit Katastropik Pada Peserta Tunggakan Iuran JKN Kecamatan Tamalate Kota Makassar Tahun 2019

\begin{tabular}{ccc}
\hline Pengetahuan dan Riwayat Penyakit & Jumlah & Persentase (\%) \\
\hline Katastropik & & \\
Pengetahuan mengenai tarif JKN & 42 & 42 \\
Baik & 68 & 68 \\
Kurang & &
\end{tabular}


Dian Saputra Marzuki, Muh. Yusri Abadi : Analysis on the Ability to ....

\begin{tabular}{ccc}
\hline $\begin{array}{c}\text { Pengetahuan dan Riwayat Penyakit } \\
\text { Katastropik }\end{array}$ & Jumlah & Persentase (\%) \\
\hline Iya & 27 & 27 \\
Tidak & 73 & 73 \\
& & \\
Jenis Penyakit & 7 & 26,0 \\
Diabetes & 5 & 18,5 \\
Hipertensi & 12 & 44,4 \\
Stroke & 3 & 11,1 \\
Tumor & & \\
\hline
\end{tabular}

Berdasarkan hasil pada kategori pengetahuan responden mengenai JKN dan tarif JKN ada 42 responden (42\%) yang pengetahuannya baik, tidak banyak responden maupaun anggota keluarga yang mempunyai riwayat penyakit katastropik hanya 27 responden (27\%) dan untuk jenis penyakit stroke yang terbanyak yaitu 12 responden (44,4\%) (Tabel 4).

Tabel 5. Distribusi responden berdasarkan Hubungan ATP dan WTP pada peserta tunggakan iuran JKN Kecamatan Tamalate Kota Makassar Tahun 2019

\begin{tabular}{lcccccc}
\hline \multirow{2}{*}{ ATP } & \multicolumn{6}{c}{ Kemauan Membayar } \\
\cline { 2 - 7 } & \multicolumn{2}{c}{ Mau } & \multicolumn{2}{c}{ Tidak Mau } & \multicolumn{3}{c}{ Total } \\
\cline { 2 - 7 } & & & $\mathrm{n}$ & $\%$ & $\mathrm{n}$ & $\%$ \\
\hline ATP 1 & 23 & 23 & 36 & 36 & 59 & 59 \\
Mampu & 19 & 19 & 22 & 22 & 41 & 41 \\
Tidak Mampu & & & & & & \\
ATP 2 (Non Makanan) & 27 & 27 & 38 & 38 & 65 & 65 \\
Mampu & 16 & 16 & 19 & 19 & 35 & 35 \\
Tidak Mampu & & & & & & \\
ATP (Non Esensial) & 28 & 28 & 37 & 37 & 65 & 65 \\
Mampu & 13 & 13 & 22 & 22 & 35 & 35 \\
Tidak Mampu &
\end{tabular}

Berdasarkan hasil untuk hubungan ATP dan WTP responden pada ATP 1 responden yang mampu membayar tunggakan iuran JKN tetapi kemauan rendah sabnyak 36 responden (36\%), ATP 2 non makanan pun sama dengan ATP 1 responden mampu membayar tetapi kemuan membayarnya rendah sebanyak 38 responden (38\%), dan ATP 2 non esensial juga seperti itu responden mampu membayar tetapi kemauan untuk membayar rendah (Tidak Mau) sebanyak 37 responden (37\%) (Tabel 5). 


\section{PEMBAHASAN}

Hasil penelitian yang dilakukan di wilayah Kecamatan Tamalate bahwa pendapatan responden mayoritas berada pada kategori pendapatan yang cukup berdasarkan UMK Kota Makassar 2019. Responden banyak yang berpikir uang yang dihasilkannya pendapatan pokok maupun tambahan lebih memperioritaskan biaya kebutuhan sehari-hari dan mengesampingkan pembayaran iuran pelayanan kesehatan. Hasil penelitian ini sejalan dengan penelitian yang dilakukan oleh Mudayana yang menyatakan bahwa pendapatan keluarga memengaruhi kemampuan pasien membayar jasa pelayanan kesehatan yang telah diberikan, apabila pendapatan pasien masih kurang maka mereka menganggap bahwa mereka tidak mampu membayar jasa pelayanan kesehatan (Mudayana, 2015).

Pengeluaran makanan cukup tinggi mulai dari pengeluaran nasi, lauk pauk hingga kerupuk, pengeluaran non makanan untuk keperluan seperti barang tahan lama (alat dapur, telepon seluler) dibeli pada saat butuh saja, sedangkan pengeluaran non makanan yang paling besar adalah pembayaran listrik, gas dan air karena kebutuhan tetap setiap bulannya. Pengeluaran non esensial jumlah pengeluaran terbesarnya yaitu rokok dan jajan. Responden juga banyak yang sudah menikah dan memiliki anak sehingga pengeluaran untuk jajan anak cukup tinggi. Penelitian yang dilakukan Satria dan dawood (2017) didapatkan hasil jumlah pengeluaran konsumsi rokok dengan jumlah pengeluaran konsumsi makanan pada masyarakat miskin di Kecamatan Darul Imarah adalah negatif, negatif artinya ketika jumlah pengeluaran konsumsi rokok meningkat akan mengurangi jumlah pengeluaran untuk konsumsi makanan (Satria, 2017).

Hasil penelitian ini tidak sejalan dengan penelitian yang dilakukan oleh Karimah yang mengatakan bahwa rata-rata pengeluaran rumah tangga yang terbesar mencapai Rp 1.772.374,- dan secara berturut-turut rata-rata pengeluaran pangan sebesar Rp 825.600,-, pengeluaran pangan non esensial sebesar Rp56.000,-, dan pengeluaran non pangan sebesar Rp 890.774 (Karimah, 2015).

Hasil penelitian yang dilakukan di wilayah Kecamatan Tamalate dalam besar nya ATP 1 responden banyak yang mampu membayar iuran tunggakaan di bandingkan yang tidak mampu, ATP 2 non makanan dan non esensial pun juga 
seperti itu banyak yang mampu membayar tunggakan iuran dibandingkan yang tidak mampu. Hal ini menunjukkan kesesuaian dengan harapan pemerintah terjadi karena besar kemampuan membayar iuran JKN masyarakat tinggi dibandingkan golongan yang tidak mampu. Hal ini disebabkan karena masyarakat Kecamatan Tamalate untuk pengeluaran kebutuhan pangan, didapatkan dari hasil upah pekerjaan setiap bulannya secara rutin sehingga lebih dari cukup untuk biaya pengeluaran makanan, non makanan, dan non esensial. Penelitian Rismawati, dkk didapatkan nilai $\mathrm{p}=0,023(\mathrm{P}$ Value $<\alpha)$ sehingga terdapat hubungan antara pendapatan dengan kepatuhan membayar iuran BPJS Mandiri di Wilayah Kerja Puskesmas Batalaiworu (Rismawati, Lisnawaty, \& Jufri, 2017).

Kemauan responden membayar lebih banyak yang tidak mau membayar dibandingkan yang mau membayar dengan alasan yang mau membayar tunggakan yaitu kartu bisa digunakan, nanti kalau ada uang, sudah gajian, untuk berobat serta persalinan istri yang hamil. Selain itu alasan responden tidak mau membayar total tunggakan iuran antara lain, malas membayar, penghasilan tidak menentu, tidak ada uang, salah satu penyebab kemalasan dari hasil wawancara dengan responden yaitu kekecewaan yang pernah dialami responden dalam menggunakan kartu JKN yang terlambat terlayani dan bahkan tidak dilayani oleh pelyanan kesehatan.

Hasil penelitian yang dilakukan di wilayah Kecamatan Tamalate pada pengetahuan responden tentang JKN dan iuran JKN yaitu termasuk dalam kategori baik didukung oleh pendidikan responden yang tinggi, tetapi meskipun baik pengetahuan responden mengenai tarif JKN masih banyak yang belum tahu mengenai pembayaran bisa di tempat lain selain kantor BPJS Kesehatan seperti Alfamart, Indomart dan ATM. Namun, penelitian yang dilakukan Istiqamah (2019) menunjukkan Kemauan membayar responden jika dilihat dari pengetahuan tentang tarif adalah rendah sebanyak 60 responden (68,8\%) yang tidak mengetahui tarif perawatan dan 27 responden (31,2\%) yang mengetahui (Istiqamah \& Razak, 2019).

Responden yang memiliki riwayat penyakit katastropik ada 13 responden keluarga dan jenis penyakitnya terbanyak adalah Stroke. Hasil penelitian ini tidak sejalan dengan penelitian yang dilakukan oleh Ranti Efriyani bahwa terdapat 
hubungan dengan kepatuhan peserta mandiri membayar iuran JKN adalah tingkat pengetahuan, riwayat penyakit katastropik, jumlah anggota keluarga, jumlah pendapatan, dukungan keluarga dengan kepatuhan peserta mandiri membayar iuran JKN di Kelurahan Lubuk Buaya Tahun 2017 (Ratni, 2017).

Hubungan kemampuan membayar dengan kemauan membayar responden berdasarkan hasil yaitu kemampuan membayar ATP lebih besar dari kemauan WTP. Hal tersebut dapat menghambat kepesertaan JKN secara menyeluruh maka perlu adanya pendekatan yang lebih kepada masyarakat agar masyarakat mengerti mengenai tujuan dan manfat dari program JKN. Seperti jika sudah tidak mampu membayar iuran disebabkan penghasilan tidak menentu segera melapor untuk turun kelas pelayanan. Meskipun cakupan semesta 2019 dapat di capai tetapi jika dalam proses pembayaran iuran, penggunaan kartu dan hal-hal yang berkaitan tentang kartu JKN tidak tercapai maka perlu tidak lajut dari segala pihak. Penelitian ini tidak sejalan dengan penelitian yang dilakukan oleh Sri Setyaningsih bahwa Seluruh informan kunci mampu dan mau membayar jaminan kesehatan. Kemauan membayar iuran dikarenakan adanya pemotongan gaji yang dilakukan setiap bulan dan iuran yang sudah dibayarkan oleh informan juga bisa menutupi biaya pelayanan kesehatan jika suatu saat jatuh sakit (Setyaningsih, 2014).

Hasil penelitian ini sejalan dengan hasil penelitian Hermanto yang menunjukkan bahwa hasil perhitungan Ability to Pay (ATP) supir truk container di Kota Semarang mampu membayar Rp.25.500,- tetapi Willingness to Pay (WTP) hanya Rp.5.000 - Rp.10.000,- per bulan per kepala (Hermanto, Rimawati, \& Ernawati, 2014). Penelitian ini tidak sejalan dengan yang dilakukan oleh Mudayana dan Rusmitasari didapatkan hasil bahwa kemampuan membayar pasien memiliki rata-rata sebesar 100.033. Rata-rata kemauan membayar pasien termasuk kedalam kategori tinggi yaitu sebesar 71,26 persen (Mudayana, 2015).

\section{SIMPULAN}

Berdasarkan hasil penelitian maka dapat disimpulkan bahwa nilai ATP responden dengan menggunakan rumus ATP 1 mayoritas berada pada kategori mampu yaitu 61 responden (61\%), sedangkan untuk rumus ATP 2 mayoritas 
berada pada kategori tidak mampu untuk non makanan yaitu 54 responden (54\%) dan untuk non essensial terbanyak berada pada kategori tidak mampu yaitu 79 responden (79\%). Nilai WTP normatif responden untuk iuran JKN terbanyak berada pada kategori kelas pelayanan I yaitu 31 responden (31\%). Nilai WTP aktual responden untuk kemuan membanyar total tunggakan iuran JKN yaitu 30 responden (30\%). Pengetahuan responden mengenai JKN dan tarif iuran JKN adalah baik yaitu 42 responden (42\%). Riwayat penyakit yang dimiliki sebanyak 27 responden (27\%) dengan jenis penyakit terbanyak yaitu stroke 12 responden keluarga (44,4\%). Pihak BPJS Kesehatan untuk memberikan informasi yang mudah bagi masyarakat Kecamatan Tamalate untuk melakukan pembayaraan sebagai peserta JKN.

\section{UCAPAN TERIMA KASIH}

Terima kasih kepada Departemen Administrasi dan Kebijakan Kesehatan, FKM Unhas Makassar yang telah memberikan dukungan pada pelaksanaan penelitian ini.

\section{DAFTAR PUSTAKA}

BPJS. (2017). Laporan data jumlah peserta di Kota Makassar dan data peserta tunggakan. Makassar: Badan Penyelenggara Jaminan Sosial Kesehatan.

BPJS. (2019). Badan Penyelenggara Jaminan Sosial Kesehatan. Indonesia.

BPS. (2018). Statistical Yearbook of Indonesia 2018. Jakarta, Indonesia: Badan Pusat Statistik.

Hermanto, A. S., Rimawati, E., \& Ernawati, D. (2014). Kesiapan pekerja sektor informal (sopir truk container) dalam membayar jaminan kesehatan nasional (jkn) di kota semarang. Visikes: Jurnal Kesehatan Masyarakat, 13(2).

Istiqamah, N. F., \& Razak, A. (2019). The Pay Ability and Willingness to Pay for Treatment at Pangkajene Hospitals. Indian Journal of Public Health Research \& Development, 10(4), 845-850.

Karimah, M. (2015). Ability dan willingness to pay pekerja kerajinan tangan terhadap iuran jaminan kesehatan nasional di Desa Tutul Kecamatan Balung Kabupaten Jember. (Skripsi), Universitas Jember, Jember.

Mudayana, A. A. (2015). Analisis Kemampuan dan Kemauan Membayar Pasien Rawat Inap di RS PKU Muhammadiyah Bantul. Kes Mas: Jurnal Fakultas Kesehatan Masyarakat Universitas Ahmad Daulan, 9(1).

Ratni, E. (Faktor-faktor yang berhubungan dengan kepatuhan peserta mandiri dalam membayar iuran Jaminan Kesehatan Nasional di Kelurahan Lubuk Buaya Tahun 2017). 2017. (Skripsi), Universitas Andalas, Padang. 
Rismawati, R., Lisnawaty, L., \& Jufri, N. N. (2017). VOL. 2/NO. 8/NOVEMBER 2017; ISSN 2502-731X, Factors Related With Compliance Paying Of Bpjs Mandiri Insurance/Contribution In The Working Area Of Batalaiworu Public Health Center In 2017. Jurnal Ilmiah Mahasiswa Kesehatan Masyarakat, 2(8).

Satria, D. (2017). Korelasi Jumlah Pengeluaran Konsumsi Rokok Dengan Jumlah Pengeluaran Konsumsi Makanan Pada Masyarakat Miskin (Studi Kasus Kecamatan Darul Imarah, Kabupaten Aceh Besar). Jurnal Ilmiah Mahasiswa Ekonomi Pembangunan, 2(1), 84-93.

Setyaningsih, S. (2014). Analisis Kemampuan (ATP) Dan Kemauan (WTP) Membayar Premi Jaminan Kesehatan Pada Staf Pengajar Fakultas Ilmu Kesehatan Universitas Respati (Skripsi), Universitas Respati Yogyakarta, Yogyakarta. 